\title{
Investigation of glutathione peroxidase activity in chicken meat under different experimental conditions
}

\author{
Investigação da atividade de glutationa peroxidase em carne de frango submetida a diferentes \\ condições experimentais
}

\author{
Alexandre José CICHOSKI ${ }^{1 \star}$, Renata Bezerra ROTTA ${ }^{2}$, Gerson SCHEUERMANN ${ }^{3}$, \\ Anildo CUNHA JUNIOR ${ }^{3}$, Juliano Smanioto BARIN ${ }^{1}$
}

\begin{abstract}
Due to the fact that previous studies on the enzymatic activity of Glutathione peroxidase (GSH-Px) diverge widely in their methodology and results, this study aimed to investigate the influence of different analytical conditions on GSH-Px activity in chicken thighs from broilers that were fed different diets with different sources and concentrations of selenium. GSH-Px activity was evaluated six hours after slaughter and 120 days after frozen storage at $-18{ }^{\circ} \mathrm{C}$. The different analytical conditions included time of pre-incubation ( 0,10 and 30 minutes), reaction medium, types of substrate $\left(\mathrm{H}_{2} \mathrm{O}_{2}(0.72 \mathrm{mM}, 7.2 \mathrm{mM}\right.$, and $72 \mathrm{mM})$ and Terc-butil hydroperoxide $\left.15 \mathrm{mM}\right)$, and different buffer concentrations (buffer 1, potassium phosphate $50 \mathrm{mM} \mathrm{pH} 7.0$ + EDTA $1 \mathrm{mM}+$ mercaptoethanol $1 \mathrm{mM}$, and buffer 2, tris- HCl $50 \mathrm{mM}$ pH $7.6+$ EDTA $1 \mathrm{mM}+$ mercapthanol $5 \mathrm{mM}$ ). The results show that the highest GSH-Px activity was observed when enzyme and substrate were in contact at $22{ }^{\circ} \mathrm{C}$ without any pre-incubation, and that, when used at concentrations above $0.72 \mathrm{mM}$, hydrogen peroxide saturated the GSH-Px enzyme and inhibited its activity. The enzyme presented higher affinity to hydrogen peroxide when compared to terc-butil peroxide, and the addition of a buffer containing mercaptoethanol did not increase GSH-Px enzymatic activity. The activity of GSH-Px was not influenced by the source and concentration of selenium in the diet either. The obtained results allowed the determination of the best temperature of contact between the enzyme and substrate $\left(22^{\circ} \mathrm{C}\right)$, the optimum concentration, and the type of substrate and buffer to be used. This information is extremely useful for future studies on GSH-Px activity in meat due to the divergence and little information found in the literature.

Keywords: GSH-Px; meat chicken; enzymatic activity; selenium; buffers; substrate.
\end{abstract}

\section{Resumo}

Uma vez que estudos anteriores sobre a atividade enzimática da glutationa peroxidase (GSH-Px) divergem acerca da metodologia e dos resultados, este estudo teve por objetivo investigar a influência de diferentes condições de ensaio sobre a atividade da GSH-Px em coxas de frangos, oriundos de diferentes dietas, nas quais se variaram a fonte e a concentração de selênio. As atividades da GSH-Px foram determinadas seis horas após o abate e 120 dias após o armazenamento a $-18{ }^{\circ} \mathrm{C}$. As diferentes condições de ensaio envolveram a pré-incubação ( 0 , 10 e 30 minutos), o meio de reação, os tipos de substratos $\left[\mathrm{H}_{2} \mathrm{O}_{2}(0,72 \mathrm{mM}, 7,2 \mathrm{mM}\right.$ e $72 \mathrm{mM})$ e terc-butil hidroperóxido $\left.15 \mathrm{mM}\right]$ e as concentrações diferentes de tampões [tampão 1 (fosfato de potássio $50 \mathrm{mM} \mathrm{pH} \mathrm{7,0} \mathrm{+} \mathrm{EDTA} 1 \mathrm{mM}+$ mercaptoetanol $1 \mathrm{mM}$ ) e tampão 2 (tris- $\mathrm{HCl} 50 \mathrm{mM} \mathrm{pH} \mathrm{7,6} \mathrm{+} \mathrm{EDTA} 1 \mathrm{mM}$ + mercaptoetanol $5 \mathrm{mM}$ )] no meio de reação. Os resultados mostraram que: i) a maior atividade da GSH-Px foi observada quando a enzima e o substrato foram colocados em contato a $22^{\circ} \mathrm{C}$ sem qualquer pré-incubação; ii) o peróxido de hidrogênio, quando utilizado em concentrações acima de $0,72 \mathrm{mM}$, saturou a enzima GSH-Px e inibiu sua atividade; iii) a enzima GSH-Px apresentou maior afinidade para o substrato peróxido de hidrogênio, quando comparado ao peróxido de terc-butil, e iv) a adição do tampão mercaptoetanol não promoveu aumento na atividade da enzima GSH-Px. A atividade da GSH-Px também não foi influenciada pela fonte e pela concentração de selênio vindo pela dieta. Os resultados obtidos permitiram definir qual a melhor temperatura de contato entre a enzima e o substrato $\left(22^{\circ} \mathrm{C}\right)$ e qual a melhor concentração e o tipo de substrato e de tampão a serem utilizados. Essas informações poderão servir de base para a execução de futuros trabalhos envolvendo a determinação da atividade da GSH-Px em carnes, pois há contradições nas poucas informações existentes na literatura.

Palavras-chave: GSH-Px; carne de frango; atividade enzimática; selênio; tampão; substrato.

\section{Introduction}

Glutathione peroxidase (GSH-Px) is a selenoenzyme that is able to slow down and prevent oxidative reactions in muscular tissues by controlling free radicals formation from preexisting

peroxides (ARAI et al., 1994). GSH-Px is naturally found in bones and inhibits lipid oxidation in both live tissues and post-slaughter meat (CHAN; DECKER, 1994). Hence, GSH-Px

\footnotetext{
Received 16/3/2010

Accepted 28/2/2012 (004730)

Departament of Technology and Science of Food, Universidade Federal de Santa Maria - UFSM, Bairro Camobi, CEP 97105-900, Santa Maria, RS, Brazil,

e-mail: ajcichoski@hotmail.com

2 Departament of Food Engineering, Universidade Regional Integrada do Alto Uruguai e das Missões - URI, Campus de Erechim, Av. Sete de Setembro, 1621, CEP 99700-000, Erechim, RS, Brazil

${ }^{3}$ EMBRAPA Pigs and Poultry, BR 153, Km 110, CP 21, CEP 89700-000, Concórdia, SC, Brazil

${ }^{*}$ Corresponding author
} 
activity has been measured in several types of meat, such as cattle (LEE; MEI; DECKER, 1996a, 1996b; O'GRADY et al., 2001), pork (MAHAN; PARRETT, 1996; HERNÁNDEZ; PARK; RHEE, 2002), and poultry (MOREIRA et al., 2001; SURAI, 2002; CARRERAS et al., 2004, HOAC et al., 2006). GSH-Px catalyzes the detoxification of hydrogen peroxide $\left(\mathrm{H}_{2} \mathrm{O}_{2}\right)$ in vitro presenting high specificity for this substrate (ROTRUCK et al., 1973). In fact, such reaction takes place in vivo through a parallel oxidation of the reduced form of glutathione (GSH), a tripeptide. The resulting molecule, oxidized glutathione (GSSG), is reduced back through a parallel reaction with the reduced form of nicotinamide adenine dinucleotide phosphate (NADPH). This reaction is catalyzed by the glutathione reductase enzyme (ROVER JUNIOR et al., 2001).

Considering these reactions, Paglia and Valentine (1967) proposed an analytical method for the determination of GSH-Px enzymatic activity in erythrocytes. According to this method, the decrease in the NADPH absorbance at $340 \mathrm{~nm}$, in the presence of $\mathrm{H}_{2} \mathrm{O}_{2}$, is proportional to GSH-Px enzymatic activity. Since its proposal, this has been the standard method for measuring GSH-Px activity in all kinds of samples due to its convenience and reliability. (CARRERAS et al., 2004; DAUN; AKESSON, 2004a, 2004b; HOAC et al., 2006; HOLOVSKÁ JUNIOR et al., 2003). Despite the existence of several studies on GSH-Px activity measurement, the influence of experimental parameters for estimating GSH-Px activity is still not clear. The standard technique is an indirect and complex method, and there are some uncertainties about the reaction mechanisms involved. In addition, the studies conducted on this topic diverge widely in their methodology and results. Due to the little information available about the analytical method and the divergences concerning the determination of GSH-Px activity in the muscle, this study aimed to investigate the influence of different experimental conditions on the activity of GSH-Px in chicken thighs. Therefore, the type and concentration of peroxide, the buffers, the influence of reaction time and temperature at the analytical signal, as well as the influence of broiler's diet and the effect of storage were studied, and the optimized conditions were established.

\section{Material and methods}

\subsection{Materials}

One thousand and one hundred forty male chickens (lineage Ross) were fed five different diets: T1, without selenium supplementation; T2, supplemented with inorganic selenium (sodium selenite) at the concentration of $0.15 \mathrm{mg} \cdot \mathrm{kg}^{-1}$; T3, supplemented with inorganic selenium at the concentration of $0.35 \mathrm{mg} / \mathrm{kg}$; T4, supplemented with organic selenium (Sel-Plex ${ }^{\circledR}$ ) at the concentration of $0.15 \mathrm{mg} \cdot \mathrm{kg}^{-1}$; and T5, supplemented with organic selenium at the concentration of $0.35 \mathrm{mg} \cdot \mathrm{kg}^{-1}$. The diets were elaborated from basic formulations following recommended nutritional requirements (ROSTAGNO et al., 2005).

At the age of 42 days, ninety birds were slaughtered, and their thigh meat was used as raw material for evaluating the glutathione peroxidase (GSH-Px) activity. The study was divided into two stages: the first stage comprised five experiments, in which the thigh meat enzymatic activity was evaluated six hours after slaughter; the second stage was carried out on based on the results obtained in the first stage. In the second stage, the material used to measure GSH-Px activity was raw meat frozen for 120 days at $-18{ }^{\circ} \mathrm{C}$. The samples were randomly chosen among the chickens fed $\mathrm{T} 2$ and $\mathrm{T} 5$ diets. In both stages, three replicates were made for each analysis. Means, standard deviation, analysis of variance, and the Tukey's test of means were performed at $5 \%$ confidence level using Statistica (Statsoft, Tulsa, USA) software, version 6.1 .

\subsection{GSH-Px determination in chicken thigh meat six hours after slaughter}

The enzymatic extract was obtained according to the modified method proposed by Devore et al. (1983). Skinless and visually fat-free chicken thighs were homogenized with tris- $\mathrm{HCl}$ buffer $50 \mathrm{mM}$ at $\mathrm{pH} 7.6$ and $5{ }^{\circ} \mathrm{C}$ at the $1: 5 \mathrm{w} / \mathrm{v}$ ratio. Next, the mixture was centrifuged $\left(27.500 \mathrm{~g}, 30\right.$ minutes, $\left.4{ }^{\circ} \mathrm{C}\right)$, and the supernatant was filtered and once again centrifuged under the same conditions.

The GSH-Px activity of enzymatic extract was determined according to a modification of the method proposed by Paglia and Valentine (1967). The reaction medium was composed of potassium phosphate buffer $171 \mathrm{mM}$, sodium azide $4.28 \mathrm{mM}$, EDTA $2.14 \mathrm{mM}$, reduced glutathione $6 \mathrm{mM}$, NADPH $0.9 \mathrm{mM}$, and glutathione reductase $2 \mathrm{U} \cdot \mathrm{mL}^{-1}$. The reaction took place at $22{ }^{\circ} \mathrm{C}( \pm 1)$, starting with the addition of $\mathrm{H}_{2} \mathrm{O}_{2} 0.72 \mathrm{mM}$. The absorbance of the samples was measured at $340 \mathrm{~nm}$ using a spectrophotometer. The measurements were taken every 15 seconds for 300 seconds. The GSH-Px enzymatic activity can be expressed in enzymatic units per $\mathrm{mL}$ of sample $\left(\mathrm{U} \cdot \mathrm{mL}^{-1}\right)$, U.L $L^{-1}, \mathrm{U}^{-1}{ }^{-1}$ of tissue, $\mathrm{U}_{\mathrm{g}} \mathrm{g}^{-1}$ of protein, or $\mathrm{U}_{\mathrm{mg}} \mathrm{m}^{-1}$ of hemoglobin (PUNCHARD; KELLY, 1996). In the present study, the GSH-Px enzymatic activity was expressed as $\mathrm{U}_{\mathrm{g}} \mathrm{g}^{-1}$ of tissue and was calculated using Equation 1:

$U / g=\Delta A / \min \times F$

where $\mathrm{F}$ is a constant used for converting absorbance per minute $(\Delta \mathrm{A} / \mathrm{min})$ into enzymatic units $(\mathrm{U})$. $\mathrm{F}$ is calculated by the following Equation 2:

$F=\frac{(R V / S V) \times 5}{6.22}$

where $\mathrm{RV}$ is the reaction volume (in $\mathrm{mL}$ ); $\mathrm{SV}$ is the sample volume (in $\mathrm{mL}$ ); 5 is the volume (in $\mathrm{mL}$ ) used to dilute $1 \mathrm{~g}$ of tissue during the enzyme extraction; and 6.22 is the NADPH molar extinction coefficient (in $\mathrm{Mm} . \mathrm{cm}^{-1}$ ).

\subsection{GSH-Px determination in chicken thigh after 120 days of storage at $-18{ }^{\circ} \mathrm{C}$}

The enzymatic extract was obtained according to the same procedure described above, except from the fact that two different buffers where tested in the reaction medium: buffer 1 , composed of potassium phosphate $50 \mathrm{mM}$ at $\mathrm{pH}$ of 
7.0, EDTA $1 \mathrm{mM}$, and mercaptoethanol $1 \mathrm{mM}$; and buffer 2, composed of tris- $\mathrm{HCl} 50 \mathrm{mM}$ at $\mathrm{pH}$ of 7.6, EDTA $1 \mathrm{mM}$ and mercaptoethanol $5 \mathrm{mM}$. In both cases, the extraction took place at $5{ }^{\circ} \mathrm{C}$ with a $1: 5 \mathrm{w} / \mathrm{v}$ ratio. Next, the mixture was centrifuged as described above and the supernatant was filtered and once again centrifuged under the same conditions.

The GSH-Px activity of enzymatic extract was determined according to the same method described above. In this stage, however, the reaction took place at $36^{\circ} \mathrm{C}$ after a pre-incubation time of 10 or 30 minutes. In addition, two substrates were tested under different concentrations: $\mathrm{H}_{2} \mathrm{O}_{2}$ at the concentrations of $0.72 \mathrm{mM}, 7.2 \mathrm{mM}$, and $72 \mathrm{mM}$; and terc-butil hydroperoxide at the concentration of $15 \mathrm{mM}$. The absorbance was measured under the same conditions previously described, and GSH-Px enzymatic activity was expressed in $\mathrm{U}^{-1}{ }^{-1}$ of tissue and calculated using Equations 1 and 2.

\section{Results and discussion}

\subsection{GSH-Px activity in chicken thigh meat six hours after slaughter}

Table 1 shows the GSH-Px activity values in chicken thigh meat six hours after slaughter considering the different diets of the birds with inorganic or organic selenium.

The results show that changing the selenium source and concentration in the diet did not influence GSH-Px activity in chicken thighs. Holovská Junior et al. (2003) studied the effect of four diets (without selenium, $0.2 \mathrm{mg}$ of inorganic selenium. $\mathrm{kg}^{-1}, 0.2 \mathrm{mg}$ of organic selenium. $\mathrm{kg}^{-1}$, and $0.3 \mathrm{mg}$ of organic selenium. $\mathrm{kg}^{-1}$ ) on chicken liver GSH-Px activity. They observed that changing the birds diet did not influence the chicken liver GSH-Px activity. A study conducted by Daun and Akesson (2004a) reports similar results: the differences in GSH-Px activity in chicken thighs were not related to the levels of selenium in the diets. Such results could be attributed to the fact that the selenium ingested by the birds is used for producing several selenoproteins besides GSH-Px. Thus, selenium distribution in the bird body is regulated by its metabolic needs (DAUN; AKESSON, 2004b). For example, birds subjected to heat or cold stress present an increase in the levels of the selenoprotein Type I Iodothyronine Deiodinase, which regulates body temperature (ARTHUR; NICOL; BECKETT, 1993). Since thirty selenoproteins have been previously reported, it is quite possible that the selenium added to the birds diet in the present study was used for other metabolic activities than the GSH-Px synthesis. The GSH-Px activity values observed in our study were similar to those observed by HOAC et al. (2006) in chicken breast $\left(0.050 \mathrm{U.g}^{-1}\right)$ but lower than those observed by

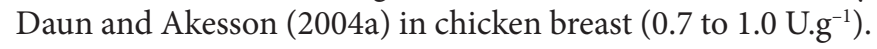

According to Punchard and Kelly (1996), the ideal decay rate of absorbance for the GSH-Px enzyme is between 0.01 and $0.05 \mathrm{U} / \mathrm{min}$. In the first stage of the present study, the absorbance decay rate was much lower than these values. Therefore, it was necessary to study the influence of changing the enzymatic assay conditions on GSH-Px activity in order to optimize the method and also study details of the GSH-Px enzymatic kinetics.
Stagsted (2006) observed the same behavior when measuring GSH-Px activity in milk using the standard Paglia and Valentine method and also obtained different results from other studies. Therefore, they decided to vary the enzymatic assay conditions in order to optimize the method.

\subsection{GSH-Px activity in chicken thigh after 120 days of storage at $-18^{\circ} \mathrm{C}$}

Effect of different hydrogen peroxide concentrations on GSH-Px activity

The GSH-Px enzyme reduces several reactive oxygen species (ROS) including hydrogen peroxide (CHAUDIERE et al., 1984). The first step in such reduction reaction is a direct oxidation of selenolate anion $\left(\mathrm{E}-\mathrm{Se}^{-}\right)$or selenol $(\mathrm{E}-\mathrm{SeH})$, which are the two catalytically active forms of the selenocysteine residue contained in GSH-Px (PRABHAKAR et al., 2005). This reaction is shown in Equation 3.

$\mathrm{E}-\mathrm{SeH}+\mathrm{H}_{2} \mathrm{O}_{2} \rightarrow \mathrm{E}-\mathrm{SeOH}+\mathrm{H}_{2} \mathrm{O}$

After the oxidation of the GSH-Px active center by hydrogen peroxide, the enzyme reacts with a reduced glutathione (GSH) molecule forming an enzyme-glutathione complex (Equation 4). Next, this complex reacts with another GSH molecule, which reduces back the GSH-Px enzyme and releases an oxidized glutathione molecule (Equation 5). Finally, GSH-Px reduces once again the oxidized glutathione molecule in the presence of NADPH (PRABHAKAR et al., 2005).

$\mathrm{E}-\mathrm{SeOH}+\mathrm{GSH} \rightarrow \mathrm{E}-\mathrm{Se}-\mathrm{SG}+\mathrm{H}_{2} \mathrm{O}$

$E-S e-S G+G S H \rightarrow E-S e H+G S S G$

Since hydrogen peroxide is a substrate for the GSH-Px enzyme, its concentration controls the reaction speed. Thus, lack or excess of hydrogen peroxide in the reaction medium could affect the enzymatic kinetics. In order to evaluate the effect of hydrogen peroxide concentration on the GSH-Px reaction rate, three different hydrogen peroxide concentrations were used in the preparation of the reaction medium: $0.72 \mathrm{mM}$, $7.2 \mathrm{mM}$, and $72 \mathrm{mM}$. The results shown in Figure 1 show that the reaction rates were significantly affected by hydrogen peroxide concentration. According to Lehninger, Nelson and Cox (1995), all enzymes can be saturated by a proper substrate,

Table 1. Influence of different diets (T1, T2, T3, T4, and T5) on GSH-Px enzymatic activity $\left({\mathrm{U} . \mathrm{g}^{-1}}^{-1}\right)$ in chicken thigh meat six hours after slaughter. The data are expressed as mean \pm standard deviation $(n=3)$.

\begin{tabular}{lc}
\hline \multicolumn{1}{c}{ Treatment } & Enzymatic activity $\left(\mathrm{U} \cdot \mathrm{g}^{-1}\right.$ tissue $)$ \\
\hline T1 (no Se) & $0.051^{\mathrm{A}}( \pm 0.031)$ \\
T2 (inorganic Se at $\left.0.15 \mathrm{mg} \cdot \mathrm{kg}^{-1}\right)$ & $0.083^{\mathrm{A}}( \pm 0.14)$ \\
T3 (inorganic Se at $\left.0.35 \mathrm{mg} \cdot \mathrm{kg}^{-1}\right)$ & $0.045^{\mathrm{A}}( \pm 0.003)$ \\
T4 (organic Se at $\left.0.15 \mathrm{mg} \cdot \mathrm{kg}^{-1}\right)$ & $0.077^{\mathrm{A}}( \pm 0.015)$ \\
T5 (organic Se at $\left.0.35 \mathrm{mg} \cdot \mathrm{kg}^{-1}\right)$ & $0.085^{\mathrm{A}}( \pm 0.019)$ \\
\hline
\end{tabular}

${ }^{\mathrm{A}}$ Different letters in the same column indicates significant difference by the Tukey test $(\mathrm{p}<0.05)$. 
but the substrate concentration required to saturate each one of them is variable. In this study, hydrogen peroxide concentrations above $0.72 \mathrm{mM}$ reduced the reaction rate, i.e., saturating the enzyme and inhibiting its catalytic activity. Splittgerber and Tappel (1979) used three types of hydroperoxides at different concentrations as substrates for mice liver GSH and GSH-Px keeping the enzyme concentration constant. They observed that an increase in hydroperoxides concentration caused a decrease in the reaction rates. Lin and Hultin (1978) also reported that the GSH-Px enzyme is easily saturated by hydrogen peroxide. Therefore, high concentrations of hydrogen peroxide reduce the reaction rate by slowing down the initial reaction (Equation 3 ).

\section{Effect of different pre-incubation conditions of the reaction medium on the GSH-Px activity}

According to previous findings, the GSH-Px enzymatic activity is affected by the pre-incubation time and temperature of the reaction medium. In the study of Carreras et al. (2004), the reaction medium was pre-incubated at $30^{\circ} \mathrm{C}$ for 5 minutes prior to the addition of hydroperoxide and absorbance readings. On the other hand, Moreira et al. (2001) and Penha-Silva et al. (2005) pre-incubated the medium at $37^{\circ} \mathrm{C}$ for 10 minutes before adding the starter. Some authors report that the immediate reaction takes place at $37{ }^{\circ} \mathrm{C}$, without pre-incubation (LINDMARKMANSSON et al., 2001; HOLOVSKÁ JUNIOR et al., 2003; HOAC et al., 2006). Other studies report the use of temperatures for reactions that range from $20{ }^{\circ} \mathrm{C}$ to $25^{\circ} \mathrm{C}$ (LEE; MEI; DECKER, 1997; HERNÁNDEZ; PARK; RHEE, 2002). In the present study, the first stage comprised essays carried out at $22{ }^{\circ} \mathrm{C}$ without pre-incubation. In the second stage, different times and temperatures of pre-incubation were tested.

In the reaction catalyzed by the GSH-Px enzyme, the oxidized glutathione (GSSG) generated from glutathione (GSH) (Equation 6) is instantly and continuously reduced in the presence of the GSH-Px enzyme (Equation 7). This keeps a constant glutathione level, preventing the redox cycle from stopping (ROVER JUNIOR et al., 2001; PENHA-SILVA et al., 2005).

$2 \mathrm{GSH}+\mathrm{H}_{2} \mathrm{O}_{2} \rightarrow \mathrm{GSH}-\mathrm{Px} \rightarrow \mathrm{GSSG}+2 \mathrm{H}_{2} \mathrm{O}$

$G S S G+N A D P H+H \rightarrow G S R E D \rightarrow 2 G S H+N A D P^{+}$

In this redox cycle, the NADPH molecule behaves as an electron donor, which is oxidized. In the standard Paglia and Valentine (1967) method, this oxidation is photometrically monitored by the absorption decay at $340 \mathrm{~nm}$, which is correlated with the GSH-Px enzymatic activity. Figure 2 shows that the GSH-Px enzymatic activity during the five minutes of reaction is influenced by the different pre-incubation conditions of the reaction medium $\left(22^{\circ} \mathrm{C}\right.$ immediate, $36^{\circ} \mathrm{C} / 30 \mathrm{~min}$, and $\left.36{ }^{\circ} \mathrm{C} / 10 \mathrm{~min}\right)$. The reaction rate was $0.0003 \mathrm{abs} / \mathrm{min}$ when the sample was pre-incubated at $36^{\circ} \mathrm{C}$ for 30 minutes; $0.0007 \mathrm{abs} / \mathrm{min}$ for pre-incubation at $36^{\circ} \mathrm{C}$ for 10 minutes; and $0.0058 \mathrm{abs} / \mathrm{min}$ for the reaction at $22{ }^{\circ} \mathrm{C}$ without preincubation. Such behavior could be attributed to the fact that this enzymatic reaction is rather fast, probably taking place

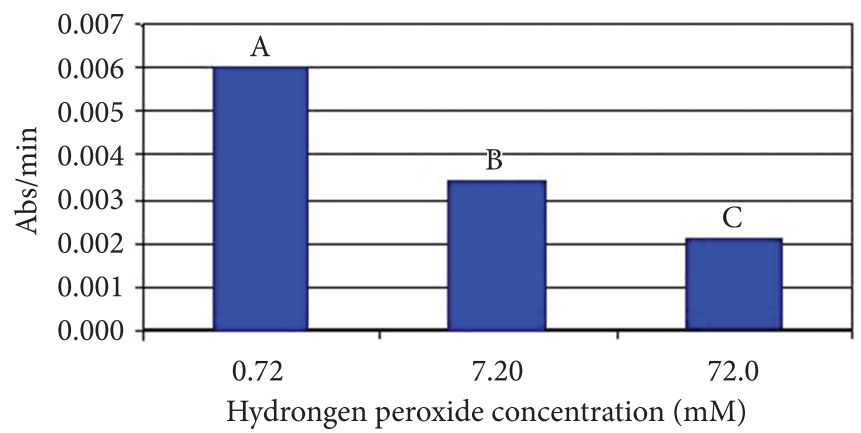

Figure 1. Effect of different hydrogen peroxide concentrations on the reaction rates $\left(\mathrm{abs} \cdot \mathrm{min}^{-1}\right)$ of the conversion of hydrogen peroxide by the GSH-Px enzyme for the immediate reaction at $22^{\circ} \mathrm{C}$ in raw chicken thigh meat frozen for 120 days at $-18^{\circ} \mathrm{C}$. The data are expressed as mean \pm standard deviation $(n=3) .{ }^{A, B, C}$ Different letters indicates significant difference by the Tukey test $(\mathrm{p}<0.05)$.

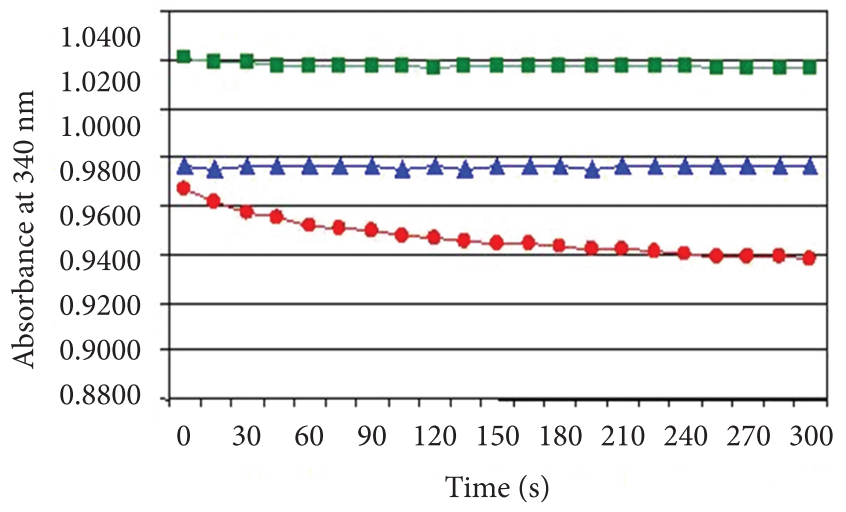

Figure 2. Influence of different pre-incubation conditions of the reaction medium on NADPH absorbance at $340 \mathrm{~nm}$ (GSH-Px enzymatic activity) during the reaction period. Symbols: $(\bigcirc)$ immediate reaction at $22^{\circ} \mathrm{C} ;(\boldsymbol{\Delta})$ reaction after water bath at $36^{\circ} \mathrm{C}$ for 30 minutes; ( $)$ reaction after water bath at $36^{\circ} \mathrm{C}$ for 10 minutes. The data are expressed as mean \pm standard deviation $(n=3)$.

during the pre-incubation period in water bath. Therefore, when the absorbance readings were made, the NADPH was almost fully oxidized yielding reaction rates closer to zero. This behavior was expected, since the reactions catalyzed by cellular GSH-Px enzyme, found in the muscles, are faster than those catalyzed by extracellular enzymes, found in milk and blood plasma (STAGSTED, 2006). Those two enzyme subspecies are structurally and functionally different from each other. Extracellular GSH-Px enzyme presents a higher resistance to high temperatures when compared to cellular GSH-Px enzyme (LINDMARK-MANSSON et al., 2001). Therefore, GSH-Px might have been inhibited by the temperatures used for preincubation in the present study.

\section{Effect of different substrate types on the GSH-Px activity}

Hydrogen peroxide and terc-butil hydroperoxide are substrates for GSH-Px enzyme presenting Michaelis-Menten constants $\left(\mathrm{K}_{\mathrm{m}}\right)$ of 0.003 and $0.059 \mathrm{mM}$, respectively (BRENDA, 
2007). In other words, GSH-Px enzyme presents higher affinity to hydrogen peroxide. The reaction rates of the conversion of hydrogen peroxide and terc-butil hydroperoxide by GSH-Px enzyme at $22^{\circ} \mathrm{C}$ are shown in Figure 3. The GSH-Px enzymatic activity was $0.0028 \mathrm{abs} / \mathrm{min}$ for the conversion of terc-butil hydroperoxide and $0.0077 \mathrm{abs} / \mathrm{min}$ for the conversion of hydrogen peroxide confirming that GSH-Px has higher affinity to the latter. Avissar et al. (1991) found similar enzymatic activity values of milk GSH-Px when using hydrogen peroxide and tercbutil hydroperoxide as substrates.

\section{Effect of the presence of different buffers in the reaction medium} on the GSH-Px activity

The determination of GSH-Px enzyme activity in animal tissues requires a previous extraction, since the enzyme is found inside the mitochondria and cytosol of the muscle cells (CHAN; DECKER, 1994). During extraction, some conditions must be controlled in order to preserve the enzyme. Those factors include $\mathrm{pH}$ and electrolytes concentration in the buffer solution, extraction temperature, and solution dilution (FENNEMA, 1993).

The GSH-Px optimal pH is close to 8.0 (PAGLIA; VALENTINE, 1967), and its activity is minimal at $\mathrm{pH}$ lower than 6.0 (MILLS, 1959). Therefore, the GSH-Px activity is often measured at the 7.0-7.6 pH range (PUNCHARD et al., 1996). High electrolyte concentrations affect the proteins solubility (FENNEMA, 1993). According to Chen, Lindmark-Mansson and Akesson (2000), low buffer concentrations increase the extraction of the GSH-Px enzyme. The extraction temperature is also critical since high temperatures can cause thermal inactivation of the enzyme. Thus, in this study, the buffer solution was kept at $4{ }^{\circ} \mathrm{C}$, the homogenization took place under ice bath, and the centrifugation was performed at $4^{\circ} \mathrm{C}$.

The active center of GSH-Px contains the amino acid selenocysteine, a derivative of cysteine in which a sulfur atom is substituted by selenium. Selenocysteine facilitates the GSH-Px oxidation by generating a covalent bond between two atoms of selenium. These bonds make the protein structure more stable impairing GSH-Px extraction and reducing its reactivity with the substrate (LEHNINGER; NELSON; COX, 1995). According to Arai et al. (1994), mercaptoethanol is a stabilizing agent which forms a reversible enzyme-inhibitor (FARFÁN, 1994), a useful characteristic when one wants to prevent spontaneous oxidation during the GSH-Px enzyme extraction. Therefore, it was expected that the presence of mercaptoethanol in the buffer solution favored the enzymatic extraction. To study the effect of different buffer solutions on the GSH-Px enzymatic activity, tris- $\mathrm{HCl}$ buffer $50 \mathrm{mM} \mathrm{pH} 7.6$ and two other types of extraction buffers containing mercaptoethanol were used. The results are shown in Figure 4. The GSH-Px enzymatic activity was $0.0062 \mathrm{abs} / \mathrm{min}$ using an extraction medium with buffer number 1, $0.0072 \mathrm{abs} / \mathrm{min}$ using buffer number 2, and $0.0114 \mathrm{abs} / \mathrm{min}$ using buffer number 3 . The results show that the highest enzymatic activity was observed when buffer number 3 was used (tris- $\mathrm{HCl} 50 \mathrm{mM} \mathrm{pH} \mathrm{7.6),} \mathrm{suggesting} \mathrm{that}$ mercaptoethanol was not useful for improving the enzyme extraction. Chaudiere et al. (1984) observed inhibition of the GSH-Px enzymatic activity when adding mercaptoethanol to the reaction medium obtaining the same results hereby reported.

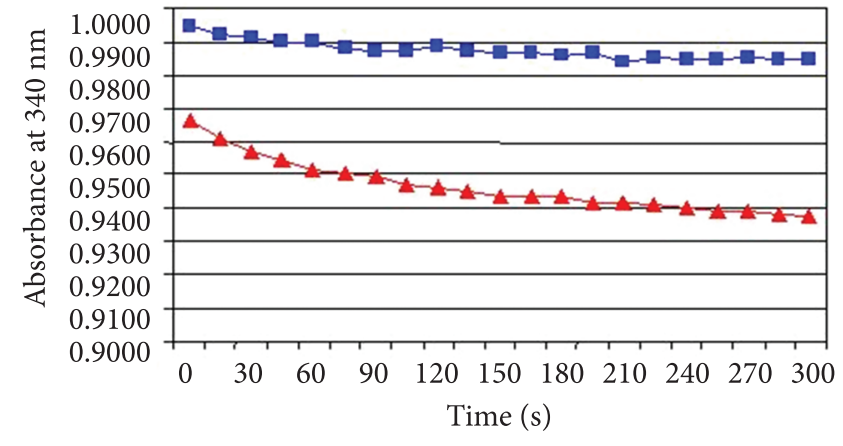

Figure 3. Effect of substrate type on NADPH absorbance at $340 \mathrm{~nm}$ (GSH-Px enzymatic activity) during the reaction period for the immediate reaction at $22{ }^{\circ} \mathrm{C}$. Symbols: $(\boldsymbol{\Delta})$ hydrogen peroxide at $0.72 \mathrm{mM}$; $(\mathbf{\square})$ terc-butil hydroperoxide at $15 \mathrm{mM}$. The data are expressed as mean \pm standard deviation.

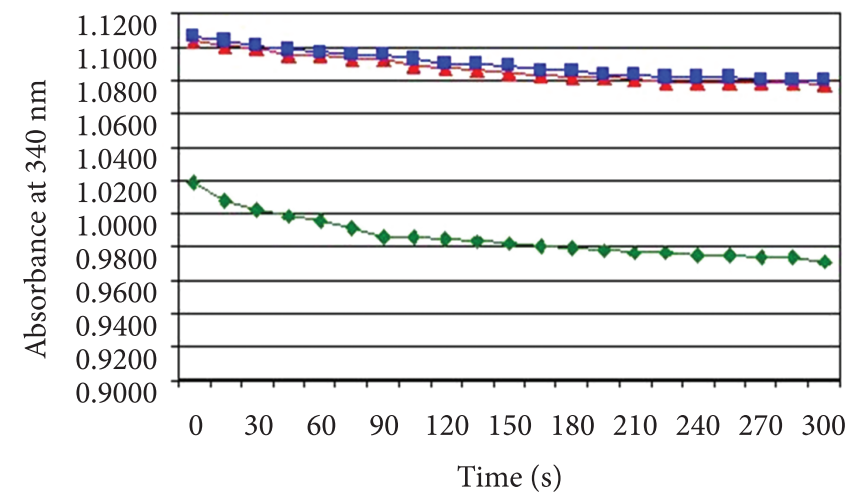

Figure 4. Influence of the presence of buffers in the reaction medium on NADPH absorbance at $340 \mathrm{~nm}$ (GSH-Px enzymatic activity) during the reaction period for the immediate reaction at $22{ }^{\circ} \mathrm{C}$. Symbols: ( ) buffer 1 (potassium phosphate $50 \mathrm{mM}$ at pH 7,0 + EDTA $1 \mathrm{mM}+$ mercaptoethanol $1 \mathrm{mM}$ ); (A) buffer 2 (tris- $\mathrm{HCl} 50 \mathrm{mM}$ at $\mathrm{pH}$ 7,6 + EDTA $1 \mathrm{mM}+$ mercaptoethanol $5 \mathrm{mM}$ ); ( ) buffer 3 (tris- $\mathrm{HCl}$ $50 \mathrm{mM} \mathrm{pH} \mathrm{7,6).} \mathrm{The} \mathrm{data} \mathrm{are} \mathrm{expressed} \mathrm{as} \mathrm{mean} \pm$ standard deviation $(\mathrm{n}=3)$.

\section{Conclusions}

The data obtained in this study help to elucidate the reaction mechanisms that take place in the method used for measuring the GSH-Px enzymatic activity. The different parameters of enzymatic assay studied showed that the activity of GSH-Px is influenced by some parameters related to the analytical method. When hydrogen peroxide was added at concentrations above $0.72 \mathrm{mM}$, the GSH-Px enzyme was saturated and its activity was inhibited. GSH-Px decreased its activity in contact with terc-butil hydroperoxide when compared to hydrogen peroxide, confirming its higher affinity to the latter. Other important findings were that the highest GSH-Px activity was observed when enzyme and substrate were put into contact at $22^{\circ} \mathrm{C}$ without any pre-incubation and that the use of reaction media containing mercaptoethanol was not associated with an increase the GSH-Px enzymatic activity, as previous reported in literature. The results obtained allowed to define the best 
temperature of contact between the enzyme and the substrate, the best concentration, and type of substrate and buffer to be used.

\section{References}

ARAI, T. et al. Glutathione peroxidase activity in tissues of chickens supplemented with dietary selenium. Comparative Biochemistry and Physiology, v. 107A, p. 245-248, 1994.

ARTHUR, J. R.; NICOL, F.; BECKETT, G. J. Selenium deficiency, thyroid hormone metabolism, and thyroid hormone deiodinases. American Journal of Clinical Nutrition Supply, v. 57, p. 236- 239, 1993.

AVISSAR, N. et al. Partial sequence of human plasma glutathione peroxidase and immunological identification of milk glutathione peroxidase as the plasma enzyme. Journal of Nutrition, v. 121, p. 1243-1249, 1991. PMid:1861172.

BRENDA. The Comprehensive Enzyme Information System. Disponível em: <http://www.brenda.uni-koeln.de> Acesso em: 02 maio 2007.

CARRERAS, I. F. et al. Influence of enrofloxacin administration and ?-tocopheryl acetate supplemented diets on oxidative stability of broiler tissues. Poultry Science, v. 83, p. 1-7, 2004. PMid:14761077.

CHEN, J.; LINDMARK-MANSSON, H.; AKESSON, B. Optimisation of a coupled enzymatic assay of glutathione peroxidase activity in bovine milk and whey. International Dairy Journal, v. 10, p. 347-351, 2000.

CHAN, K. M.; DECKER, E. A. Endogenous skeletal muscle antioxidants. Food Science and Nutrition, v. 34, n. 4, 403-426, 1994. PMid:7945896.

CHAUDIERE, J.; WILLHELMSEN, E. C.; TAPPEL, A. L. Mechanism of selenium-glutathione peroxidase and its inhibition by mercaptocarboxylic acids and other mercaptans. The Journal of Biological Chemistry, v. 259, n. 2, p. 1043-1050, 1984. PMid:6693375.

DAUN, C.; AKESSON, B. Comparison of glutathione peroxidase activity, and of total and soluble selenium content in two muscles from chicken, turkey, duck, ostrich and lamb. Food Chemistry, v. 85, p. 295-303, 2004a. http://dx.doi.org/10.1016/j. foodchem.2003.07.009

DAUN, C.; AKESSON, B. Glutathione peroxidase activity, and content of total and soluble selenium in five bovine and porcine organs used in meat production. Meat Science, v. 66, p. 801-807, 2004b. http:// dx.doi.org/10.1016/S0309-1740(03)00178-5

DEVORE, V. R. et al. Thiobarbituric acid values and glutathione peroxidase activity in meat from chickens fed a seleniumsupplemented diet. Journal of Food Science, v. 48, p. 300-301, 1983. http://dx.doi.org/10.1111/j.1365-2621.1983.tb14860.x

FARFÁN, J. A. Modificação química. Química de proteínas aplicada à ciência e tecnologia dos alimentos. 2. ed. Campinas: Editora Unicamp, 1994. cap. 4, p. 65-105.

FENNEMA, O. R. Química de los alimentos. 2. ed. Zaragoza: Acribia, 1993. cap. 6, p. 416-536.

HERNÁNDEZ, P.; PARK, D.; RHEE, K. S. Chloride salt type/ionic strength, muscle site and refrigeration effects on antioxidant enzymes and lipid oxidation in pork. Meat Science, v. 61, p. 405-410, 2002. http://dx.doi.org/10.1016/S0309-1740(01)00212-1

HOAC, T. et al. Influence of heat treatment on lipid oxidation and glutathione peroxidase activity in chicken and duck meat. Innovative Food Science \& Emerging Technologies, v. 7, p. 88-93, 2006. http://dx.doi.org/10.1016/j.ifset.2005.10.001
HOLOVSKÁ JUNIOR, K. et al. Antioxidant enzyme activities in liver tissue of chickens fed diets supplemented with various forms and amounts of selenium. Journal of Animal and Feed Sciences, v. 12, p. 143-152, 2003.

LEE, S. K.; MEI, L.; DECKER, E. A. Lipid oxidation in cooked turkey as effect by added antioxidant enzymes. Journal of Food Science, v. 61, p. 726-728, 795, 1996a.

LEE, S. K.; MEI, L.; DECKER, E. A. Role of antioxidant enzymes in the development of oxidative rancidity in cooked and salted muscle foods. Meat Focus International, v. 5, p. 310-311, 1996b.

LEE, S. K.; MEI, L.; DECKER, E. A. Influence of sodium chloride on antioxidant enzyme activity and lipid oxidation in frozen ground pork. Meat Science, v. 46, n. 4, p. 349- 355, 1997. http://dx.doi. org/10.1016/S0309-1740(97)00029-6

LEHNINGER, A. L.; NELSON, D. L.; COX, M. M. Princípios de bioquímica. 2. ed. São Paulo: Sarvier, 1995. cap. 8, p.147-176.

LIN, T. S.; HULTIN, H. O. Glutathione peroxidase of skeletal muscle. Journal of Food Biochemistry, v. 2, p. 39-47, 1978. http://dx.doi. org/10.1111/j.1745-4514.1978.tb00602.x

LINDMARK-MANSSON, $\mathrm{H}$. et al. The effect of storage and heat treatment on glutathione peroxidase in bovine milk and whey. International Dairy Journal, v. 11, p. 71- 81, 2001. http://dx.doi. org/10.1016/S0958-6946(01)00034-6

MAHAN, D. C.; PARRETT, N. A. Evaluating the efficacy of seleniumenriched yeast and sodium selenite on tissue selenium retention and serum glutathione peroxidase activity in grower and finisher swine. Journal of Animal Science, v. 74, p. 2967-2974, 1996. PMid:8994911.

MILLS, G. C. The purification and properties of glutathione peroxidase of erythrocytes. Journal of Biological Chemistry, v. 234, p. 502-506, 1959. PMid:13641249.

MOREIRA, J. et al. Efeito de fonte e níveis de selênio na atividade enzimática da glutationa peroxidase e no desempenho de frangos de corte. Ciência e Agrotecnologia, v. 25, n. 3, p. 645-649, 2001.

O'GRADY, M. N. et al. Effects of dietary supplementation with vitamin $\mathrm{E}$ and organic selenium on the oxidative stability of beef. Journal of Animal Science, v. 79, p. 2827-2834, 2001. PMid:11768111.

PAGLIA, D. E.; VALENTINE, W. N. Studies on the quantitative and qualitative characterization of erythrocyte glutathione peroxidase. Journal of Laboratory and Clinical Medicine, v. 70, n. 1, p. 158-169, 1967. PMid:6066618.

PENHA-SILVA, N. et al. Determinação da faixa de referência de glutationa peroxidase no soro de bovinos sadios. Bioscience Journal, v. 21, n. 2, p. 89-93, 2005.

PRABHAKAR, R. et al. Elucidation of the mechanism of selenoprotein glutathione peroxidase catalysed hydrogen peroxide reduction by two glutathione molecules: a density functional study. Biochemistry, v. 44, p. 11864-11871, 2005. PMid:16128588. http:// dx.doi.org/10.1021/bi050815q

PUNCHARD, N. A.; KELLY, F. J. Glutathione peroxidase: activity and steady-state level of mRNA. In: DARET, K. et al. Free radicals: a pratical approach. London: Oxford University Press, 1996. cap. 16, p. 227- 240.

ROSTAGNO, H. S. et al. Tabelas brasileiras para aves e suínos: composição de alimentos e exigências nutricionais. 2. ed. Viçosa: Universidade Federal de Viçosa, 2005. 186 p.

ROTRUCK, J. T. et al. Selenium: biochemical role as component of glutathione peroxidase. Science, v. 179, p. 588-590, 1973. PMid:4686466. http://dx.doi.org/10.1126/science.179.4073.588

ROVER JUNIOR, L. et al. Sistema antioxidante envolvendo o ciclo metabólico da glutationa associado a métodos eletroanalíticos 
na avaliação do estresse oxidativo. Química Nova, v. 24, n. 1, p. 112-119, 2001.

SPLITTGERBER, A. G.; TAPPEL, A. L. Steady state and pre-steady state kinetic properties of rat liver selenium-glutathione peroxidase. The Journal of Biological Chemistry, v. 254, n. 19, p. 9807-9813, 1979. PMid:489570.
STAGSTED, J. Absence of both glutathione peroxidase activity and glutathione in bovine milk. International Dairy Journal, v. 16, p. 662-668, 2006. http://dx.doi.org/10.1016/j.idairyj.2005.08.013

SURAI, P. F. Selenium in poultry nutrition- antioxidant properties, deficiency and toxicity. World's Poultry Science Journal, v. 58, p. 333- 347, 2002. http://dx.doi.org/10.1079/WPS20020026 